\title{
Influence of substrate on the richness and composition of Neotropical cave fauna
}

\author{
TAMIRES ZEPON ${ }^{1,2}$ and MARIA ELINA BICHUETTE ${ }^{2}$ \\ ${ }^{1}$ Programa de Pós-Graduação em Ecologia e Recursos Naturais, Universidade Federal de São Carlos, \\ Rodovia Washington Luís, Km 235, Caixa Postal 676, 13565-905 São Carlos, SP, Brazil \\ ${ }^{2}$ Laboratório de Estudos Subterrâneos, Departamento de Ecologia e Biologia Evolutiva, Universidade Federal \\ de São Carlos, Rodovia Washington Luís, Km 235, Caixa Postal 676, 13565-905 São Carlos, SP, Brazil
}

Manuscript received on July 14, 2016; accepted for publication on April 10, 2017

\begin{abstract}
The food base in the subterranean environment consists mainly of allochthonous materials. In this environment the resources are distributed generally in a heterogeneous dispersed way and the distribution of resources and their availability determine where the terrestrial invertebrates will reside, which is important for understanding ecological relationships and to establish conservation strategies. Thus, we tested how the complexity of substrates influences the richness and composition of the subterranean terrestrial invertebrates in the Presidente Olegário karst area, southeastern Brazil. We carried out collections in six caves during both dry and wet seasons, using combined collection methods. We observed different distributions in relation to the substrate, because the environmental heterogeneity increases the amount of available niches for the fauna. Some taxa showed a preference for specific substrates, probably related to the availability of food resources and humidity and to body size restriction, emphasizing the niche differentiation between species. Anthropogenic impacts can cause irreversible alterations in the subterranean fauna because the subterranean environment is dependent on the surface for input of trophic resources. On-going impacts in the Presidente Olegario karst area, like agriculture, pastures, gas extraction, and hydroelectric projects, are therefore a serious threat to subterranean biodiversity and this region should be prioritized for conservation.
\end{abstract}

Key words: Brazil, communities, conservation, food web, terrestrial invertebrates, trophic resources.

\section{INTRODUCTION}

The subterranean environment, or hypogean, consists of interconnected subsurface spaces with different dimensions that range from millimetric spaces to caves (i.e., natural cavities accessible to humans). This environment presents many terrestrial habitats (e.g., caves, cracks and crevices) (Howarth 1983, Juberthie 2000), which possesses

Correspondence to: Tamires Zepon

E-mail: tazepon@gmail.com a variety of substrates such as sand, clay, silt and rocky blocks (Poulson and White 1969, Culver and Pipan 2009).

The hypogean environment may be classified into entrance, twilight and aphotic zones (Poulson and White 1969). The permanent darkness, which defines the aphotic zone, and consequent absence of photoperiods, results in a lack of photoautotrophic organisms, which generally results in conditions of food scarcity (Poulson and White 1969, Poulson and Lavoie 2000, Culver and Pipan 2009). Thus, 
energy resources are produced by chemoautotrophic bacteria or are brought from the surface (by water, wind or occasionally by animals) and are composed of organic matter, guano, carcasses, etc (Barr 1967, Howarth 1983).

These resources are heterogeneously dispersed (Howarth 1983, Culver and Pipan 2009) and the distributions of resources and their availability contribute to determining where the terrestrial invertebrates will reside (Poulson and Culver 1969, Culver and Pipan 2009). Moreover, because the food resources consist mainly of allochthonous items (i.e., items present in a different place from the origin, in this case, items transported from the epigean environment), the subterranean food webs are truncated, and only two trophic levels (detritivores and predators) are primarily represented (Gibert and Deharveng 2002).

The richness of terrestrial invertebrates is high in Brazilian caves, where arachnids (e.g., spiders and harvestmen), insects (e.g., crickets and hemipterans) and other taxonomic groups (e.g., diplopods, isopods and collembolans) are common (Trajano and Bichuette 2010). The invertebrates are the main component of the cave terrestrial community and, in general, come from hygrophilous lineages, i.e., with preference for humid environments (Cullingford 1962, Howarth 1983, Trajano and Bichuette 2006). According to ecological-evolutive classification of Schiner-Racovitza, the subterranean organisms can be trogloxenes (must return periodically to epigean environment to complete the life cycle); troglophiles (able to establish population in both epigean and subterranean environment) and troglobites (restricted to subterranean environment). Troglobites may also present troglomorphisms: modifications associated to isolation in this environment (e.g., eyes and melanic pigmentation reduction) (Barr and Holsinger 1985).

We investigated how the complexity of substrates influences the richness and composition of the subterranean terrestrial invertebrates in Presidente Olegário karst area, southwest of Brazil. In this study we tested the following hypotheses: (1) the subterranean terrestrial invertebrates richness and abundance is higher on substrates with organic matter; and (2) the taxon occurrence on substrates is correlated with the food resource type.

The Presidente Olegário (PO) karst area possesses more than 250 caves (Grupo Pierre Martin de Espeleologia - GPME, personal communication). However, studies focusing on its subterranean fauna are limited and primarily descriptive: Secutti and Bichuette (2013) describes its subterranean ichthyofauna; Simões et al. (2014) includes a faunistic list for three caves; Cardoso et al. (2014) and Souza et al. (2016) include a description of a troglobite Amphipoda (Hyalella veredae) and a troglophile Tricladida (Girardia pierremartini), respectively; Resende et al. (2016) describe the associations between Emesinae (Hemiptera) and spiders. Only the study of Resende and Bichuette (2016) discusses the spatial distribution, habitat occupation and interactions among terrestrial invertebrate predators.

There are few studies focusing on the cave community in this region, where biodiversity is threatened by agriculture, pastures, gas extraction, and hydroelectric projects, among other anthropogenic pressures. Moreover, faunistic inventories and taxonomic and ecological studies that provide information about spatial and temporal distribution of organisms are needed for establishing conservation strategies (Trajano and Bichuette 2006, Trajano et al. 2012). Finally, the subterranean environment is vulnerable to disturbance due to dependence of imported nutrients from epigean environment (Trajano and Bichuette 2006, Trajano 2000, 2010), thus impacts in surroundings caves can jeopardize the subterranean fauna. 


\section{MATERIALS AND METHODS}

\section{STUDY AREA}

The karst area of Presidente Olegário $\left(18^{\circ} 25^{\prime} 4^{\prime \prime}\right.$ $\mathrm{S}, 46^{\circ} 25^{\prime} 4^{\prime \prime} \mathrm{W}$ ), northwestern Minas Gerais state, southeastern Brazil (Figure 1a-b) is part of the Bambuí Geomorphological Unit (Auler et al. 2001) and, to date, more than 250 caves have been recorded within it (Grupo Pierre Martin de Espeleologia - GPME, personal communication). The vegetation is composed of cerrado (savannahlike vegetation) (Ab'Saber 1977), interspersed by plants that are typical of dry forests in the limestone outcrops. The climate is classified as sub-warm and semi-humid tropical, with a dry season that lasts four to five months (Nimer 1989).

We carried out collections in six limestone caves: LapaVereda da Palha cave (VP) (18¹5'18.77" S, 4607'33.63" W), Lapa da Fazenda São Bernardo cave (SB) (18 $16^{\prime} 36.83$ " S, 460' 45.52" W), Lapa Zé de Sidinei cave (ZS) $\left(18^{\circ} 18^{\prime} 05.62\right.$ " S, 46 $05^{\circ} 40.63^{\prime}$ W), Lapa Arco da Lapa cave (AL) (18¹2'31.3" S, 4608'53.3" W), Lapa do Moacir cave (LM) (18 $11^{\circ}$ '09.67' S, 46 09'34.49" W) and Toca do Charco cave (TC) (18 $11^{\circ}$ '05.63" S, 4609'39.31” W) (Figure 1c).

\section{SAMPLING}

We performed the sampling of terrestrial invertebrates over five collection occasions (September/ 2013, January, April, June and September/2014) that covered both the dry and wet seasons. Only the Lapa do Moacir cave was sampled over four occasions due to unfeasible climatic conditions on one occasion. In order to sample as many substrates as possible, we used different collection methodologies according to types of substrates available in each cave. Indeed, it is not possible to standardize the methodologies in different caves due to the heterogeneity and complexity of available substrates for fauna.
Moreover, the volume of cave galleries is also variable, which makes it difficult to standardize sampling. Furthermore, different methods have different efficiency to access determined taxonomic groups and, therefore, combined methods are essential for accurately estimating species richness (Bichuette et al. 2015).

We carried out the collections by visual searching and by Quadrats methods $\left(0.25 \mathrm{~m}^{2}\right.$ of area by Quadrat) (Krebs 1989). We explored different substrates: sediment banks, walls, rocky blocks, bat guano piles and other organic matter sources (detritus, roots, leaf litter and trunks). Bat guano, parietal and concretion substrates were sampled only by visual searching. Parietal and concretion substrates cannot be sampled using Quadrats method. We used Winkler extractors for fauna associated with leaf litter when this substrate was available, which occur only in the Lapa Vereda da Palha. The sampling methods and the area and time of collection in each cave were standardized among collection occasions (Table I). Based on the components, we grouped the substrates into 11 categories: rock (RO); concretions (CO); soil (sand and/or clay) (SO); soil and rock (SRO); soil and gravel (SGR); soil, rock and vegetal debris (SRVD); soil, gravel and vegetal debris (SGVD); soil and vegetal debris (SVD); vegetal debris (VD); soil, rock and guano (SRG); guano (GUA). The substrates CO, SGR, SGVD and GUA were frequently wet.

The terrestrial invertebrates were fixed in loco in formalin 4\% (Turbellaria and Oligochaeta), alcohol 50\% (Diplopoda) and alcohol 70\% (other taxa). We identified the specimens using the less inclusive taxonomic level and established the morphotypes. Part of the material was sent to experts for precise identifications: specimens belonging to Orthoptera were sent to Márcio P. Bolfarini; Formicidae to Lívia P. Prado; Reduviidae (Hemiptera) to Hélcio Gil-Santana; Isoptera to Maurício M. Rocha, Isopoda to Camile 

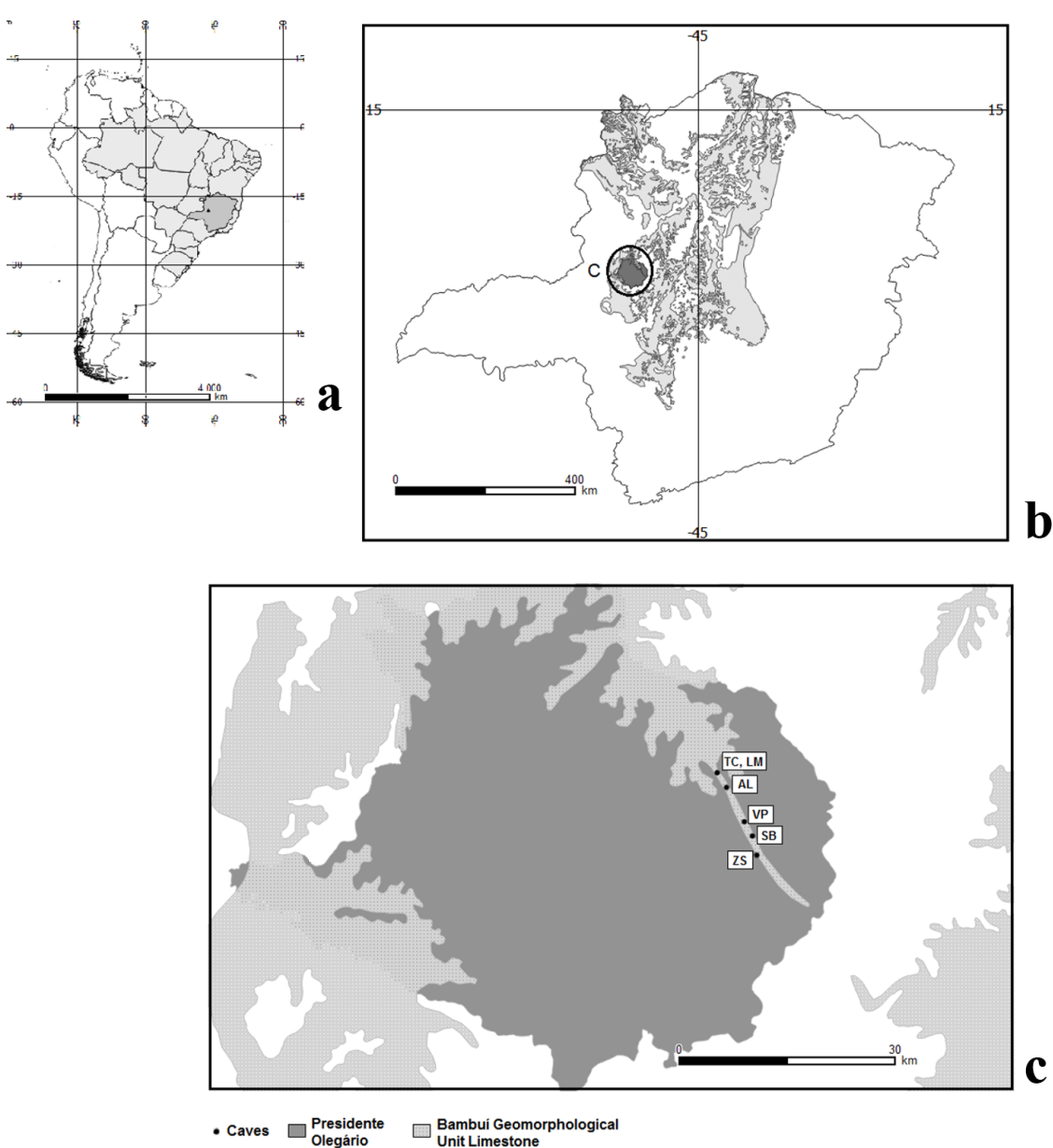

Figure 1 - Presidente Olegário karst area, Minas Gerais, Brazil. (a) South America; (b) Minas Gerais state and Presidente Olegário municipality; (c) Sampled caves. VP = Lapa Vereda da Palha cave, SB = Lapa da Fazenda São Bernardo cave, ZS = Lapa Zé de Sidinei cave, $\mathrm{AL}=$ Lapa Arco da Lapa cave, $\mathrm{LM}=$ Lapa do Moacir cave, $\mathrm{TC}=$ Toca do Charco cave.

TABLE I

Collection method and effort for sampling of invertebrates in the Presidente Olegário caves, Minas Gerais, Brazil.

Caves

\section{Visual searching $\left(\text { area in } \mathrm{m}^{2}\right)^{1}$}

\section{Visual searching} (time in minutes) ${ }^{1}$

\section{Number of Quadrats}

Winkler extractor (volume of leaf litter in $\left.\mathbf{c m}^{3}\right)^{2}$
Number of collection occasions

\begin{tabular}{|c|c|c|c|c|c|}
\hline Lapa Vereda da Palha & 203.4 & 360 & 9 & 400 & 5 \\
\hline $\begin{array}{c}\text { Lapa da Fazenda São } \\
\text { Bernardo }\end{array}$ & 178 & 420 & 7 & 0 & 5 \\
\hline Lapa Zé de Sidinei & 477 & 285 & 20 & 0 & 5 \\
\hline Lapa Arco da Lapa & 123.2 & 360 & 0 & 0 & 5 \\
\hline Lapa do Moacir & 57.2 & 160 & 0 & 0 & 4 \\
\hline Toca do Charco & 24.4 & 90 & 0 & 0 & 5 \\
\hline
\end{tabular}

${ }^{1}$ by collection occasion; ${ }^{2}$ mean by collection occasion. 
S. Fernandes, Chilopoda to Amazonas Chagas-Jr; Diplopoda to Jéssica S. Gallo; Scorpiones to Jonas E. Gallão; Pseudoscorpiones to Diego M. von Schimonsky; Opiliones to Marcos R. Hara, Ricardo Pinto-da-Rocha and Leonardo P.A. Resende; Ctenidae (Araneae) to Antonio D. Brescovit; Pholcidae (Araneae) to Leonardo S. Carvalho; Anapidae, Araneidae, Lyniphidae, Theridiidae, Theridiosomatidae and Tetragnathidae (Araneae) to Everton N.L. Rodrigues; other Araneomorphae to Leonardo P.A. Resende; and Gastropoda to Rodrigo Salvador. To avoid biases in the data analysis, we excluded the immature individuals for which the identification was imprecise.

Vouchers of the recorded fauna from the PO are in the process of being cataloged in Brazilian scientific reference collections: specimens of Anapidae, Araneidae, Lyniphidae, Theridiidae, Theridiosomatidae and Tetragnathidae will be reposited at Museu de Zoologia da UNISINOS, São Leopoldo, Rio Grande do Sul state; specimens of Gastropoda and Formicidae will be reposited at Museu de Zoologia da USP (MZUSP), São Paulo, São Paulo state; and the specimens of other taxa will be reposited at Laboratório de Estudos Subterrâneos da UFSCar (LES), São Carlos, São Paulo state.

\section{DATA ANALYSIS}

Images of some specimens were taken with a Leica DFC 295 video camera attached to a Leica M205C with a Planapo 1.0x objective. Figures were produced from stacks of imagens using LAS (Leica Application Suite) v3.7. We built Box-Plots diagrams with the richness and abundance data to verify how the fauna is distributed among the different substrates. The richness and abundance mean and confidence intervals were calculated. To statistically test the data, we checked the normality (Shapiro and Wilk 1965) and applied nonparametric analysis of variance (Kruskal-
Wallis test) (Kruskal and Wallis 1952) followed by Mann-Whitney pairwise test (Mann and Whitney 1947) to verify if the richness was significantly distinct among the different substrates. Then, we applied a nonparametric multivariate analysis (NPMANOVA) (Anderson 2001) using the BrayCurtis distance with 9999 permutations to verify if the faunal composition (i.e., relative abundances of different morphotypes) among the substrates is different, i.e., if the substrates are unique considering this variable. We used the $\mathrm{R}$ version 3.3.1 (R Core Team 2016) for building box-plots and calculate the means and confidence intervals and the PAST version 2.17 software (Hammer et al. 2001) for the normality, Kruskal-Wallis and MannWhitney tests and NPMANOVA analysis.

\section{RESULTS}

The substrate categories recorded in the studied caves are shown in Table II. We analyzed data of 382 morphotyphes and 3,137 individuals. Most taxa (95\% out of the total classified) were troglophile (Appendix - Supplementary Material, Figure 2ai). It was not possible to classify all invertebrates because detailed studies are necessary to know specifically how they use the caves.

By comparing the counts and the box-plots, we verified the higher values of richness and abundance in the rocky substrate and substrates that were comprised of vegetal debris, and the lower values in concretions and soil (Tables III and IV, Figure 3a-b). We observed different taxa distributions among the substrates and the richness varied significantly between them (Kruskal Wallis test, $\mathrm{p}=0.01147$ ). Furthermore, Mann-Whitney pairwise tests indicated that the rocky substrate (RO) is significantly different from concretion (CO), soil (SO), soil and rock (SRO), soil and gravel (SGR), soil, gravel and vegetal debris (SGVD,) vegetal debris (VD), soil, rock and guano (SRG) and guano (GUA). Concretions (CO) and 


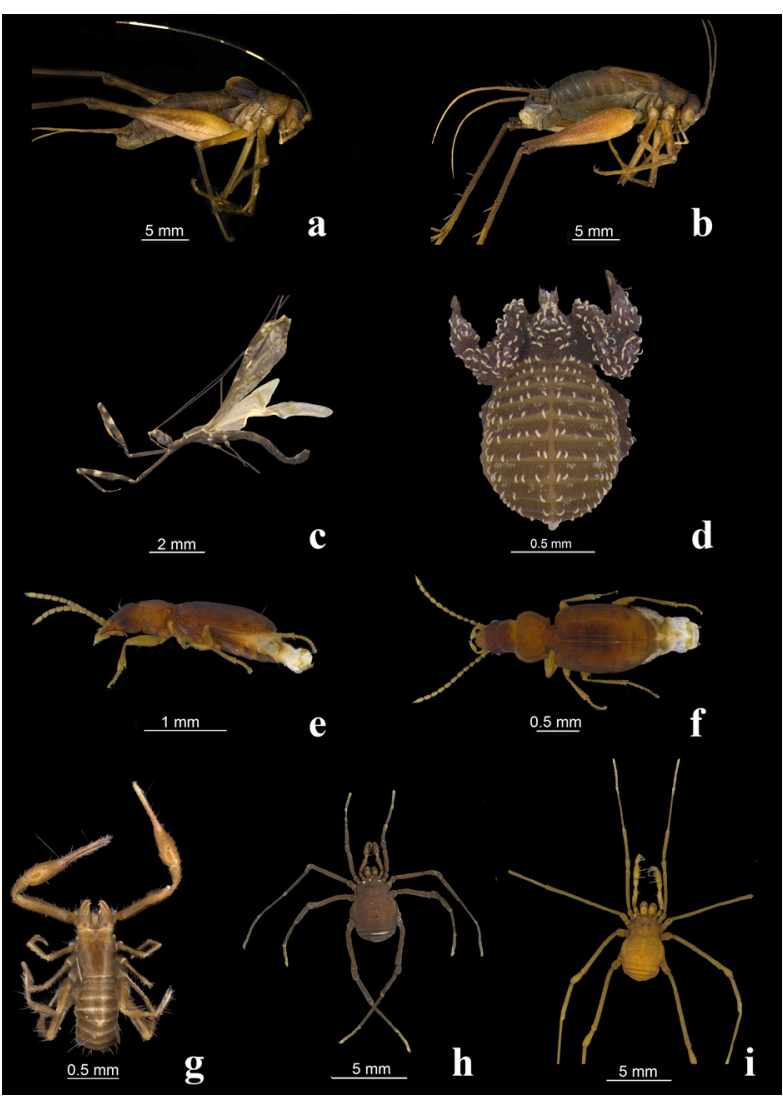

Figure 2 - Taxa recorded in Presidente Olegário caves, Minas Gerais, on rocky substrates: (a) Endecous sp. n. 1 (Orthoptera: Phalangopsidae); (b) Eidmanacris sp. n. 1 (Orthoptera: Phalangopsidae); (c) Emesinae (Hemiptera, Reduviidae); (d) Cheiridiidae (Pseudoscorpiones); and on substrates with vegetal debris: (e) lateral and (f) dorsal vista of Carabidae sp. 4 (Coleoptera); (g) Chthoniidae (Pseudoscorpiones); (h) Eusarcus hastatus and (i) Eusarcus cavernicola (Opiliones: Gonyleptidae: Pachylinae). Photo Luciana B.R. Fernandes; edition Márcio P. Bolfarini and Tamires Zepon.

soil (SO) were poor in richness and differentiated significantly from soil, rock and vegetal debris (SRVD) and soil and vegetal debris (SVD). Finally, soil and vegetal debris (SVD) was different from soil and gravel (SGR), soil, gravel and vegetal debris (SGVD), soil, rock and guano (SRG) and guano (GUA) (Table III).

Faunistic composition was also distinct between the substrates, which was evidenced by the NPMANOVA results $(\mathrm{p}=0.0001)$ and the posthoc tests (Table IV). The fauna of rocky substrates was significantly different from the other ten
TABLE II

Substrates categories present in the sampling sites of the Presidente Olegário caves, Minas Gerais, Brazil.

\begin{tabular}{ccccccc}
\hline & \multicolumn{7}{c}{ Caves } \\
\hline Substrates & VP & SB & AL & ZS & LM & TC \\
\hline RO & 1 & 1 & 1 & 1 & 1 & 1 \\
CO & 0 & 1 & 1 & 1 & 0 & 0 \\
SO & 1 & 1 & 0 & 1 & 0 & 0 \\
SRO & 1 & 1 & 1 & 1 & 0 & 0 \\
SGR & 1 & 0 & 1 & 1 & 0 & 0 \\
SRVD & 1 & 1 & 0 & 1 & 1 & 1 \\
SGVD & 1 & 0 & 1 & 0 & 0 & 0 \\
SVD & 1 & 1 & 1 & 1 & 1 & 1 \\
VD & 1 & 1 & 1 & 0 & 1 & 0 \\
SRG & 1 & 0 & 1 & 0 & 0 & 0 \\
GUA & 1 & 0 & 1 & 1 & 1 & 0 \\
\hline
\end{tabular}

$0=$ absence, 1 = presence. Caves: VP - Lapa Vereda da Palha cave, SB - Lapa da Fazenda São Bernardo cave, ZS - Lapa Zé de Sidinei cave, AL - Lapa Arco da Lapa cave, LM - Lapa do Moacir cave, TC - Toca do Charco cave. Substrates: RO - rocky; CO - concretions; SO - soil; SRO - soil and rock; SGR - soil and gravel; SRVD - soil, rock and vegetal debris; SGVD - soil, gravel and vegetal debris; SVD - soil and vegetal debris; VD - vegetal debris; SRG - soil, rock and guano; GUA - guano.

substrates categories (Table IV). In the ceiling and walls of rocky substrate environments we observed large predators of Class Arachnida (e.g., Ctenidae spiders of genus Isoctenus and species Enoploctenus cyclothorax; Pholcidae spiders of genus Mesabolivar - three morphotypes); omnivore generalists (e.g., opilionids Goniosomatinae - Mitogoniella taquara), predators of Class Insecta (e.g., hemipterans Reduviidae of genera Ploiaria and Zelurus - two morphotypes) and detritivores (e.g., orthopterans of Phalangopsidae of genus Endecous - three morphotypes, dipterans 

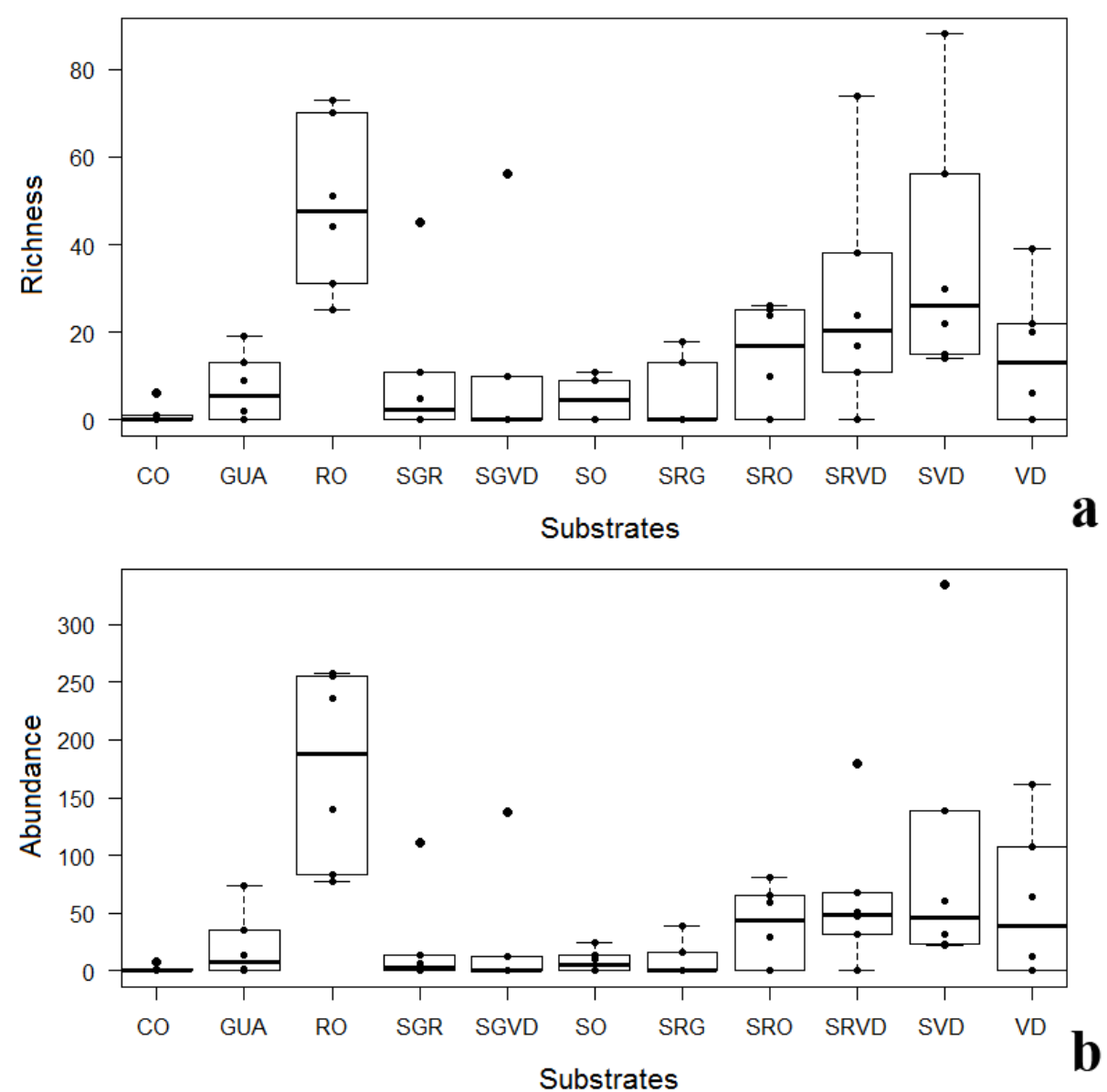

Figure 3 - Box-plots indicating medians, maximum and minimum values of (a) richness and (b) abundances invertebrates in different categories of substrates present in the Presidente Olegário caves, Minas Gerais, Brazil. The points are the (a) richness and (b) abundance for each sample. RO - rocky; CO - concretions; SO - soil; SRO - soil and rock; SGR - soil and gravel; SRVD - soil, rock and vegetal debris; SGVD - soil, gravel and vegetal debris; SVD - soil and vegetal debris; VD - vegetal debris; SRG - soil, rock and guano; GUA - guano.

Drosophilidae, lepidopterans Heterocera, diplopods Pseudonannolenidae), while in the rocky blocks we observed mainly detritivores and smaller predators (e.g., psocopterans insects and pseudoscorpions of the family Cheiridiidae) (Figure 2a-d).

Although the concretions (CO) showed low richness, the faunistic composition (mainly lepidopterans Heterocera, coleopterans Silphidae and diplopods Pseudonannolenidae) was significantly distinguished from soil and vegetal debris (SVD); and soil, rock and vegetal debris (SRVD) (Table IV). In the latter substrates we recorded mainly detritivores (e.g., gastropods, isopods of family Dubioniscidae, collembolans Entomobryomorpha, opilionids of genus Eusarcus, psocopterans, ants, and coleopterans Staphylinidae) and predators (e.g., coleopterans Carabidae, chilopods Geophilomorpha). Soil, rock and vegetal debris (SRVD) were significantly distinguished from guano (GUA) (Table IV), which presented morphotypes of Acari, dipterans Drosophilidae and Phoridae, and predators such as pseudoscorpions (genus Spelaeochernes Chernetidae) and Chilopoda (genus Lamyctes- 


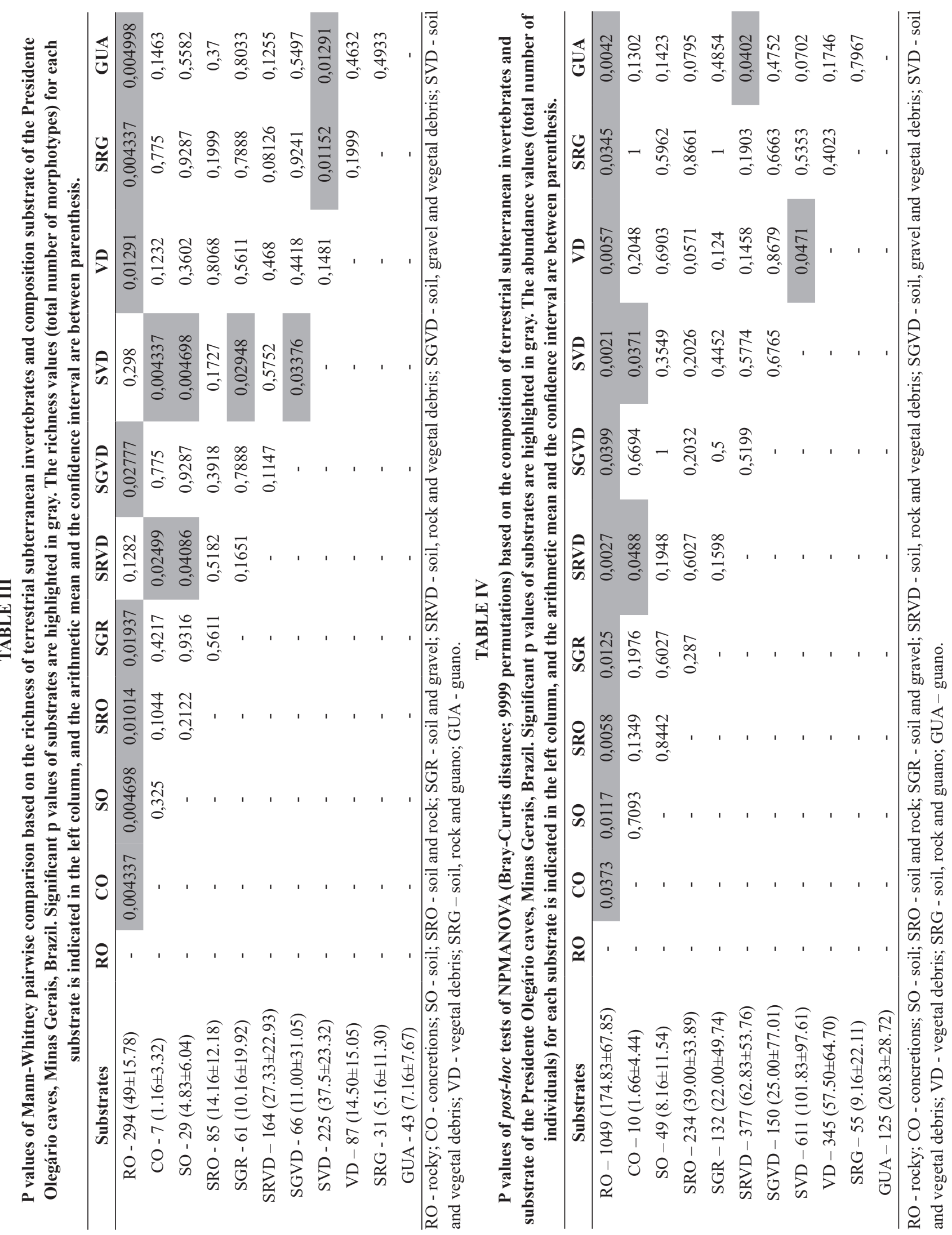


Lithobiomorpha, Henicopidae). Soil and vegetal debris (SVD) - characterized mainly by Chthoniidae (Pseudoscorpiones), Acari and Psocoptera - was also significantly different from vegetal debris (VD) (Figure 2e-i).

We did not observe differences in the faunistic compositions when we compared soil (SO) with soil, gravel and vegetal debris (SGVD), since they shared morphotypes of Entomobryomorpha, Gastropoda and Coleoptera; and when we compared soil and gravel (SGR) with soil, rock and guano (SRG) substrates, because they shared morphotypes of Psocoptera, Araneae and Acari (Table IV). The faunistic composition of soil and rock (SRO) presented a mixture of taxa of other substrates and, therefore, it was not significantly distinguished from other substrates besides rocky (RO). Furthermore, based on preference for substrates by the different taxa, we proposed a simplified and hypothetical food web based on the main groups recorded in the PO caves (Figure 4).

\section{DISCUSSION}

The distribution of the terrestrial subterranean fauna is influenced by different substrates, i.e., the physical complexity of the micro-habitats and food resources. We recorded a positive relationship between the diversity of substrates and the richness of invertebrate taxa, since some morphotypes occurred only in one particular substrate. Our results show that environmental heterogeneity increases richness, presumably by increasing available niches, as observed by other authors (MacArthur and MacArthur 1961, Poulson and Culver 1969, Poulson and White 1969, Warfe et al. 2008, Palmer et al. 2010). Moreover, according to Simões et al. 2015, the number of species colonizing the subterranean environment is positively related to availability of resources.

The fauna occurred in concretions (which is also known as tufa - a softer porous material formed by rapid deposition and evaporation (Ford and Willians 2007)) probably because it has unique climatic conditions, such as high humidity, which is an important protection against desiccation for the hygrophilous arthropods (Cullingford 1962). Moreover, the concretions represent a very efficient shelter against predators, which was evidenced in dry periods when we found a Pseudonannolenidae estivating inside the concretions. Some taxa showed a preference for guano of hematophagous bat (those which feed on blood) (e.g., mites, drosophilans and pseudoscorpions) while others prefer guano of frugivorous bat (those which feed on fruits) (e.g., centipedes Lithobiomorpha). The same pattern has been recorded in other Brazilian caves, independently of the climatic conditions (Gnaspini 1989, Trajano and Gnaspini 1991, Ferreira et al. 2000, Simões 2013), which reinforce the importance of guano as an energy resource (Gnaspini 1992).

The high richness related to vegetal debris and guano has also been reported by other authors (Poulson and Culver 1969, Peck 1976, Culver and Pipan 2009, Ferreira and Martins 2009, Simões 2013). However, vegetal and guano accumulations are gradually changed by physical and chemical processes and lose their quality (i.e., organic percentages and organic matter available, which serves as food and shelters) (Gnaspini and Trajano 2000, Simon et al. 2007, Bahia and Ferreira 2005), which was observed for substrates composed by soil, rock and guano (SRG) that showed low richness in $\mathrm{PO}$ caves.

Complex substrates, such as soil, rock and vegetal debris (SRVD); soil, gravel and vegetal debris (SGVD) and soil and vegetal debris (SVD) also showed high richness because these type of substrates retain humidity and promote protection against desiccation and prey exposure (e.g., Poulson and Culver 1969, Ferreira and SouzaSilva 2001). In contrast, homogeneous substrates, such as soil (SO), showed reduced richness and 


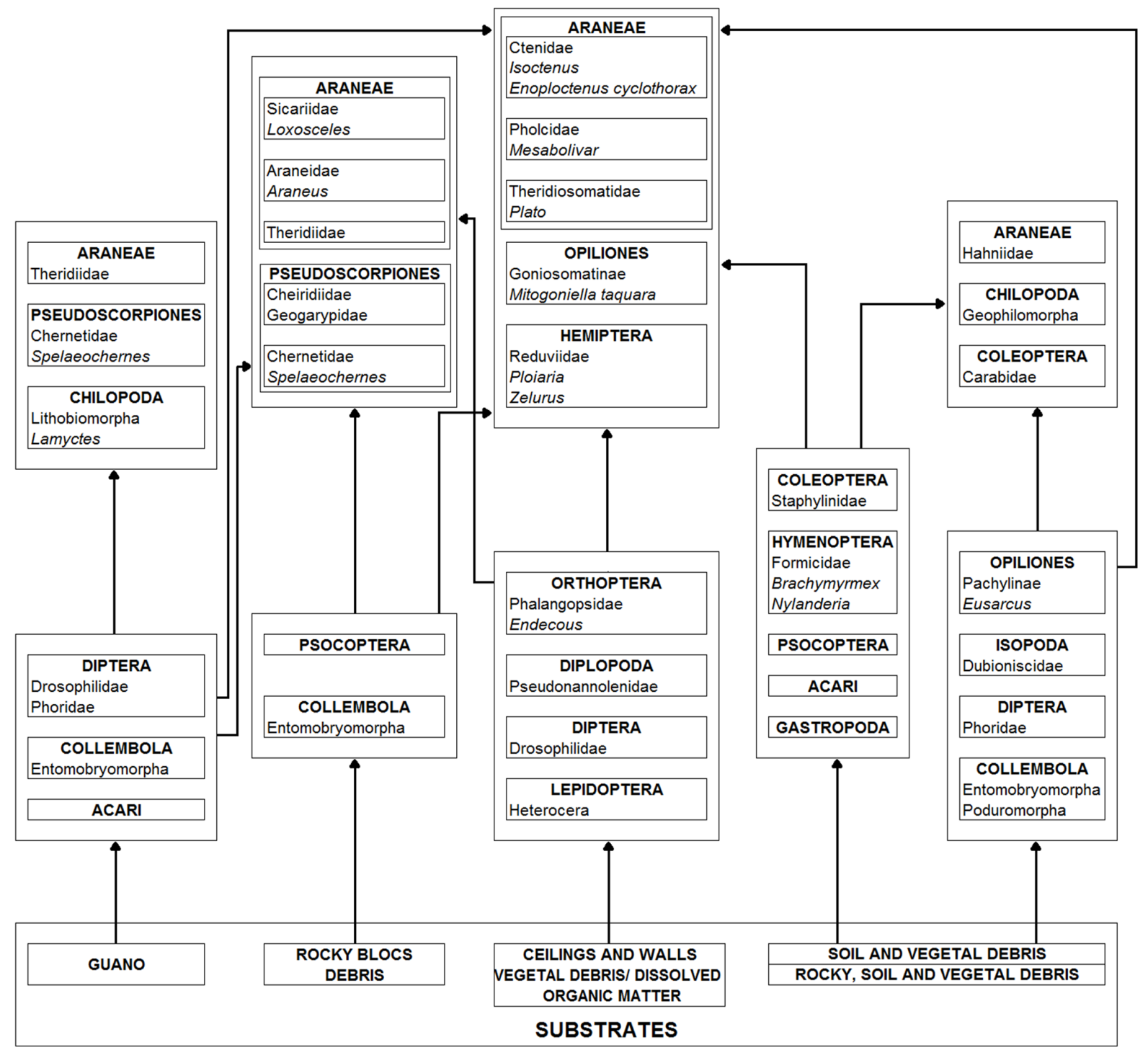

$\longrightarrow$ direction of energy flow

Figure 4 - Hypothetical food web for the subterranean fauna of the Presidente Olegário karst area, Minas Gerais, Brazil.

abundance. According to Poulson and Culver (1969) and Humphreys (1991), homogeneity makes these habitats poor in food resources, thus restricting the chance of survival for most species in the community. Thus, the lower richness and abundance in these substrates can be a consequence of high displacement due to the search for resources (e.g., food) or appropriate microclimatic conditions (e.g., moist habitats).
Other authors (e.g., Warfe et al. 2008, Palmer et al. 2010) have also linked habitat heterogeneity, which can provide increased surface area and physical refuge and the quantity or variety of limiting resources for the invertebrates, thus providing more ecological niches for community members and, consequently, increasing the diversity. 
Terrestrial communities of PO caves seem to be structured around food resources, as seen in other studies (Ferreira and Martins 1998, 2009), or to the body size restriction. It is possible to notice observing the food web proposed for the PO caves (Figure 4) that, in a general manner, the taxon occurrence in a specific type of substrate is directly associated with the presence of food resources and of humidity. Larger predators are more established in rocky substrates, such as walls and ceilings, where their prey are also present. The latter can feed on vegetal debris carried by floods (Hawes 1939, Poulson 2012). Furthermore, dissolved organic matter carried by percolation water and dripping through crevices and ceiling (Cullingford 1962, Howarth 1983, Trajano and Bichuette 2006) can be also consumed by detritivores.

We found that smaller predators are mainly established on substrates with food resources available for their prey (detritivorous animals), i.e., vegetal organic matter (debris, litter and roots) or animal (guano), corroborating the data found in the Alto do Ribeira karst area (southeastern Brazil) (Trajano and Gnaspini 1991, Trajano 2000) and in limestone caves of Minas Gerais state (Simões et al. 2015). A predominance of generalist organisms causes an overlap between the predator and decomposer levels, thus increasing the functional redundancy of subterranean ecosystems, where decomposition and nutrient cycling are crucial processes (Gibert and Deharveng 2002). Moreover, the humidity is an important characteristic for the terrestrial subterranean taxa, especially for troglobites, which can have a set of specializations related to the cave life, such as cuticle thinning, what makes them humidity dependent (Howarth 1983, Christiansen 2004).

Understanding tropical cave food webs is essential for understanding these ecosystems. The structural complexity of the habitat can affect ecological interactions, thus allowing the existence of competitors and predators and their prey in different micro-habitats (Crowder and Cooper 1982). For example, Resende and Bichuette (2016) observed the coexistence among terrestrial predators in caves of Presidente Olegário region. The authors proposed that their spatial segregation is probably more related to habitat occupation and to physical characteristics of the caves allowing high food availability, than to the inter-species competition. Furthermore, micro-habitats with different size of available space for fauna allow the coexistence of organisms with different body sizes, thus increasing the number of pathways for resource use (Kovalenko et al. 2012), which is similar to that observed in the PO caves. In turn, the increase in the number of pathways increases the resource retention and improves the resilience of the ecosystem to perturbations (Brookes et al. 2005). This large number of resource utilization pathways is also observed in caves due to the dispersed resources that, allied with functional redundancy, could increase the resilience of this ecosystem.

Faunal richness and abundance in PO caves were higher on substrates with rock and with organic matter - likely due to the availability of food resource (e.g., Poulson and Culver 1969) and to body size restriction - and in complex substrates, likely due to the protection against desiccation (e.g., litter is moister and less affected by the temperature than exposed soil; while substrates under rocks can be shelters with small-scale reservoirs of humidity) and prey exposure provided by this type of substrate (e.g., Ferreira and Souza-Silva 2001). Furthermore, the type of food resource probably determines occurrence of a taxon in specific substrates. Finally, allochthonous resources are important to cave ecosystems and their temporal and spatial availability can modify the invertebrate communities (e.g., the increase species interaction, trophic structure and community dynamics) (Anderson et al. 2008, Schneider et al. 2011). 
Changes in the epigean habitat, such as the deforestation of vegetation surrounding caves, can have negative effects on invertebrates living in caves (e.g., Taylor et al. 2005, Trajano 2000), including troglobites that are dependent on resources brought from the surface by other organisms (Culver et al. 2000). For example, trogloxene invertebrates (e.g., harvestmen, crickets) and bats leave the cave to feed, then return, depositing feces which is in turn used as food resources for subterranean fauna (Culver et al. 2000).

Considering the threats present in the region (extensive agriculture, pastures, small hydroelectric projects and gas extraction projects), the fauna of PO are considered vulnerable since the caves are widely dependent on resources carried from the surface (Trajano 2000), as was observed in other regions (Trajano and Gnaspini 1991). This is associated with unusual features of subterranean fauna, such as the stratification of fauna (i.e., preference for substrates) and peculiar trophic relationship (e.g., dependence of unusual energy source, in case, bat guano), which makes the PO caves fragile (Trajano 2000), since due to preference for substrates, disturbance in the environment can cause irreversible alterations. These characteristics are considered by other authors as unique and must be considered in conservation strategies for the subterranean realm (Sket 1999, Trajano 2000, Culver and Pipan 2009).

\section{ACKNOWLEDGMENTS}

We are greatly indebted to Grupo Pierre Martin de Espeleologia (GPME) for cave information; to Igual, E.C. for the support and help in the fieldwork; to the fieldwork helpers (Damasceno GF, Gallo JS, Joaquim LA, Resende LPA and Ribeiro IA); to the specialists who identified the material. To the farmers and their employees of Presidente Olegário for giving us free access to the caves and farms. To Célia Camargo and Jair de Sales for logistical support; to Batalha MA, Silva DM and Damasceno GF for statistical support; to Luciana B.R. Fernandes for photographs and Márcio P. Bolfarini for image editing, to Angélica M. Penteado-Dias, coordinator of Instituto Nacional de Ciência e Tecnologia dos Hymenoptera Parasitoides da Região Sudeste Brasileira (INCT Hympar Sudeste - Fundação de Amparo à Pesquisa do Estado de São Paulo - FAPESP Process 2008/57949-4 and CNPq 573802/2008-4), for stereomicroscope use to take photos; to Angélica M. Penteado-Dias, Danilo M. Silva, Marcelo A. Fernandes, José P.L. Guadanucci, Carmem S.F. Christofoletti and Jonas E. Gallão for their constructive criticism of the work. We thank Instituto Chico Mendes de Conservação da Biodiversidade (ICMBio) for permission for collections ( ${ }^{\circ}$ 28992-7); to the Programa de Pós-Graduação em Ecologia e Recursos Naturais (PPG-ERN) for the infrastructure; to Coordenação de Aperfeiçoamento de Pessoal de Nível Superior (CAPES) for PROAP funding; MEB is financed by Conselho Nacional de Desenvolvimento Científico e Tecnológico (CNPq) (Processes 303715/20111 and 57413/2014-0) and FAPESP (Processes 2008/05678-7 and 2010/08459-4); TZ was financed by CNPq (132065/2013-4). We thank the anonymous reviewers for valuable suggestions that improved the manuscript.

\section{REFERENCES}

AB'SABER AN. 1977. Os domínios morfoclimáticos na América do Sul. Primeira aproximação. Geomorfologia 52: 1-22.

ANDERSON MJ. 2001. A new method for non-parametric multivariate analysis of variance. Austral Ecol 26: 32-46.

ANDERSON WB, WAIT AD AND STAPP P. 2008. Resources from another place and time: responses to pulses in a spatially subsidized system. Ecology 89: 660-670.

AULER A, RUBBIOLI E AND BRANDI R. 2001. As grandes cavernas do Brasil. Belo Horizonte: Grupo Bambuí de Pesquisas Espeleológicas, 228 p.

BAHIA GR AND FERREIRA RL. 2005. Influência das características físico-químicas e da matéria orgânica de depósitos recentes de guano de morcego na riqueza e 
diversidade de invertebrados de uma caverna calcária. Rev Bras Zoociências 7: 165-180.

BARR TC. 1967. Observations on the ecology of caves. Am Nat 101(922): 475-491.

BARR TC AND HOLSINGER JR. 1985. Speciation in cave faunas. Ann Rev Ecol Syst 16: 313-337.

BICHUETTE ME, SIMÕES LB, VON SCHIMONSKY DM AND GALLÃO JE. 2015. Effectiveness of quadrat sampling on terrestrial cave fauna survey-a case study in a Neotropical cave. Acta Sci Biol Sci 37: 345-351.

BROOKES JD, ALDRIDGE K, WALLACE T, LINDEN L AND GANF GG. 2005. Multiple interception pathways for resource utilization and increased ecosystem resilience. Hydrobiologia 552: 135-146.

CARDOSO GM, ARAÚJO PB, BUENO AAP AND FERREIRA RL. 2014. Two new subterranean species of Hyalella Smith, 1874 (Crustacea: Amphipoda: Hyalellidae) from Brazil. Zootaxa 3: 353-368.

CHRISTIANSEN K. 2004. Adaptations: morphological (external). In: Gun J (Ed), Encyclopedia of caves and karst science, London: Fitzroy Dearborn, p. 14-18.

CROWDER LB AND COOPER WE. 1982. Habitat structural complexity and the interaction between bluegills and their prey. Ecology 63: 1802-1813.

CULLINGFORD CHD. 1962. Cave fauna and flora. In: Cullingford CHD (Ed), British caving, an introduction to speleology. London: Routledge and Kegan Paul, p. 347389.

CULVER DC, MASTER LL, CHRISTMAN MC AND HOBBS HH. 2000. Obligate cave fauna of the 48 contiguous United States. Conserv Biol 14: 386-401.

CULVER DC AND PIPAN T. 2009. The biology of caves and other subterranean habitats. Oxford: Oxford University Press, $256 \mathrm{p}$.

FERREIRA RL AND MARTINS RP. 1998. Diversity and distribution of spiders associated with bat guano piles in Morrinho Cave (Bahia State, Brazil). Divers Distrib 4: 235-241.

FERREIRA RL AND MARTINS RP. 2009. Mapping subterranean resources: The cave invertebrates distribution as indicator of food availability. Rev Bras Zoociências 11: 119-127.

FERREIRA RL, MARTINS RP AND YANEGA D. 2000. Ecology of bat guano arthropod communities in a Brazilian dry cave. Ecotropica 6: 105-116.

FERREIRA RL AND SOUZA-SILVA M. 2001. Biodiversity under rocks: the role of microhabitats in structuring invertebrate communities in Brazilian outcrops. Biodivers Conserv 10: 1171-1183.

FORD D AND WILLIANS P. 2007. Karst hydrogeology and geomorphology. England: J Wiley \& Sons, 562 p.
GIBERT J AND DEHARVENG L. 2002. Subterranean ecosystems: a truncated functional biodiversity. Bioscience 52: 473-481.

GNASPINI P. 1989. Análise comparativa da fauna associada a depósitos de guano de morcegos cavernícolas no Brasil. Primeira aproximação. Rev Bras Entomol 33: 183-192.

GNASPINI P. 1992. Bat guano ecosystems a new classification and some considerations with special references to Neotropical data. Mem Biospeol 19: 135-138.

GNASPINI PAND TRAJANO E. 2000. Guano communities in tropical caves. In: Wilkens H, Culver DC and Humphreys WF (Eds), Ecosystems of the world: subterranean ecosystems, Amsterdan: Elsevier Science, p. 251-269.

HAMMER Ø, HARPER DAT AND RYAN PD. 2001. PAST: Paleontological statistics software package for education and data analysis. Palaeontol Electron 4: 1-9.

HAWES RS. 1939. The flood factor in the ecology of caves. J Anim Ecol 8: 1-5.

HOWARTH FG. 1983. Ecology of cave arthropods. Ann Rev Entomol 28: 365-389.

HUMPHREYS WF. 1991. Experimental re-establishment of pulse-driven populations in a terrestrial troglobite community. J Anim Ecol 60: 609-623.

JUBERTHIE C. 2000. The diversity of the karstic and pseudokarstic hypogean habitats in the world. In: Wilkens H, Culver DC and Humphreys WF (Eds), Ecosystems of the world: subterranean ecosystems, Amsterdan: Elsevier, p. 17-39.

KOVALENKO KE, THOMAZ SM AND WARFE DM. 2012. Habitat complexity: approaches and future directions. Hydrobiologia 685: 1-17.

KREBS CJ. 1989. Ecological methodology. University of British Columbia, New York: Harper Collins Publishers, $654 \mathrm{p}$.

KRUSKAL WH AND WALLIS WA. 1952. Use of ranks in one-criterion analysis of variance. J Amer Statist Assoc 47: 583-621.

MACARTHUR RH AND MACARTHUR JW. 1961. On bird species diversity. Ecology 42: 594-598.

MANN HB AND WHITNEY DR. 1947. On a test of whether one of 2 random variables is stochastically larger than the other. Ann Math Stat 18: 50-60.

NIMER E. 1989. Climatologia do Brasil. Rio de Janeiro: Instituto Brasileiro de Geografia e Estatística, Departamento de Recursos Naturais e Estudos Ambientais, $421 \mathrm{p}$.

PALMER MA, MENNINGER HL AND BERNHARDT E. 2010. River restoration, habitat heterogeneity and biodiversity: a failure of theory or practice? Freshwater Biol 55: 205-222.

PECK SB. 1976. The effect of cave entrances on the distribution of cave-inhabiting terrestrial arthropods. Int J Speleol 8: 309-321. 
POULSON TL. 2012. Food sources. In: White WB and Culver DC (Eds), Encyclopedia of caves. Amsterdan: Elsevier, p. 323-334.

POULSON TL AND CULVER DC. 1969. Diversity in terrestrial cave communities. Ecology 50: 153-158.

POULSON TL AND LAVOIE KH. 2000. The trophic basis of subsurface ecosystems. In: Wilkens H, Culver DC and Humphreys WF (Eds), Ecosystems of the world: subterranean ecosystems, Amsterdan: Elsevier, p. 231-249.

POULSON TL AND WHITE WB. 1969. The cave environment. Science 165: 971-980.

R CORE TEAM. 2016. R: A language and environment for statistical computing. R Foundation for Statistical Computing, Vienna, Austria. URL https://www.R-project. org/.

RESENDE LPA AND BICHUETTE ME. 2016. Sharing the space: coexistence among terrestrial predators in Neotropical caves. J Nat Hist 50: 1-22.

RESENDE LPA, ZEPON T, BICHUETTE ME, PAPE RB AND SANTANA HG. 2016. Associations between Emesinae heteropterans and spiders in limestone caves of Southeastern Brazil, State of Minas Gerais. Neotrop Biol Conserv 11: 114-121.

SCHNEIDER K, CHRISTMAN MC AND FAGAN WF. 2011. The influence of resource subsidies on cave invertebrates: results from an ecosystem-level manipulation experiment. Ecology 92: 765-776.

SECUTTI S AND BICHUETTE ME. 2013. Ictiofauna da área cárstica de Presidente Olegário -MG, com ênfase nas espécies subterrâneas. Rev Biol 10: 13-20.

SHAPIRO SS AND WILK MB. 1965. An analysis of variance test for normality (complete samples). Biom 52: 591-611.

SIMÕES LB. 2013. Biodiversidade da fauna subterrânea na área cárstica de São Domingos, nordeste de Goiás: relevância versus visibilidade de táxons, p. 197. MSc Dissertation. Universidade Federal de São Carlos. São Carlos, Brasil. (Unpublished).

SIMÕES MH, SOUSA-SILVA M AND FERREIRA RL. 2014. Cave invertebrates in northwestern Minas Gerais State, Brazil: endemism, threats and conservation priorities. Acta Carsologica 43: 159-174.

SIMÕES MH, SOUZA-SILVA M AND FERREIRA RL. 2015. Cave physical attributes influencing the structure of terrestrial invertebrate communities in Neotropics. Subterr Biol 16: 103-121.
SIMON KS, PIPAN T AND CULVER DC. 2007. A conceptual model of the flow and distribution of organic carbon in caves. J Cave Karst Stud 69: 279-284.

SKET B. 1999. The nature of biodiversity in hypogean waters and how it is endangered. Biodivers Conserv 8: 13191338.

SOUZA S, MORAIS AL, BICHUETTE ME AND LEALZANCHET A. 2016. Two new species of freshwater flatworms (Platyhelminthes: Tricladida: Continenticola) from South American caves. Zootaxa 4092: 107-121.

TAYLOR SJ, KREJCA JK AND DENIGHT ML. 2005. Foraging range and habitat use of Ceuthophilus secretus (Orthoptera: Rhaphidophoridae), a key trogloxene in central Texas cave communities. Am Midl Nat 154: 97114.

TRAJANO E. 2000. Cave faunas in the Atlantic tropical rain forest: composition, ecology and conservation. Biotropica 32: 882-893.

TRAJANO E. 2010. Políticas de conservação e critérios ambientais: princípios, conceitos e protocolos. Estud Av 24: 135-146.

TRAJANO E AND BICHUETTE ME. 2006. Biologia subterrânea: Introdução. São Paulo: Redespeleo, 92 p.

TRAJANO E AND BICHUETTE ME. 2010. Diversity of Brazilian subterranean invertebrates, with a list of troglomorphic taxa. Subterr Biol: 7: 1-16.

TRAJANO E, BICHUETTE ME AND BATALHA MA. 2012. Environmental studies in caves: the problems of sampling, identification, inclusion, and indices. Espeleo-Tema 23(1): 13-22.

TRAJANO E AND GNASPINI P. 1991. Notes on the food webs in caves of southeastern Brazil. Mem Biospeol 8: 75-79.

WARFE DM, BARMUTA LA AND WOTHERSPOON S. 2008. Quantifying habitat structure: surface convolution and living space for species in complex environments. Oikos 117: 1764-1773.

\section{SUPPLEMENTARY MATERIAL}

Appendix: Faunistic list of taxa occurence (species/ morphotypes) in six caves presents in Presidente Olegário karst area, Minas Gerais state, southwestern Brazil. 